\title{
Регуляция геномов коронавирусов
}

\author{
Цикуниб Р.3. ${ }^{*}$, Романов Д.Е. ${ }^{2}$, Тугуз А.P. ${ }^{3}$ \\ ${ }^{1}$ ГБО ДО Республики Адыгея «Республиканская естественно-математическая школа», \\ майкоп, Россия \\ ${ }^{2}$ Академия биологии и биотехнологии ЮФУ, Ростов-на-Дону, Россия \\ ${ }^{3}$ Адыгейский государственный университет, Майкоп, Россия \\ *cikunib@gmail.com
}

Ключевые слова: PHК-интерференция, метилирование, SARS-CoV, SARS-CoV-2, MERS-CoV

Мотивация: Опасная эпидемиологическая ситуация в связи с распространением SARS-CoV-2 определяет актуальность темы. В регуляции экспрессии генов вирусов SARS-CoV, MERS-CoV и SARS-CoV-2, относящихся к одному семейству, важное значение имеют эпигенетические механизмы - РНК-интерференция и метилирование. РНК-интерференция - система контроля экспрессии генов эукариотических клеток посредством микро-РНК (miRPHК, 20-25 нуклеотидов), которая используется для обезвреживания вирусного генетического материала. Синтезируемые клетками miRPHK комплементарно связываются с участками геномов РНК-содержащих вирусов и вызывают их деградацию. Экспрессия вирусных генов контролируется метилированием - модификацией вирусной ДНК или РНК без изменения наследственной информации.

Meтоды $и$ алгоритмы: Для поиска вирусных нуклеотидных последовательностей, комплементарных клеточным микро-PHК, в геноме SARS-CoV-2 и локализации участков с высокой плотностью CpG-островков в геномах всех изучаемых PHКвирусов использованы базы данных NCBI, miRBase, а также языки программирования Python и R.

Результаты: Определены микро-РНК с наибольшим процентом сходства и покрытия (ptc-miR6463, mml-miR-3140, pab-miR11446, hpo-miR-5932-5p, prd-miR-5594-5p, hsamiR-8066, pab-miR11409d) и установлены эукариотические организмы, экспрессирующие эти микро-РНК (Populus trichocarpa, Macaca mulatta, Picea abies, Heligmosomoides polygyrus, Panagrellus redivivus, Homo sapiens). Аналогично получены премикро-РНК (nle-mir-320c-2, mle-mir-92b, prd-mir-5594, pal-mir-299b, cinmir-4143, oni-mir-10969) и соответствующие им организмы (Nomascus lencogenys, Melibe leonine, Panagrellus redivivus, Pteropus alecto, Ciona intestinalis, Oreochomis niloticus). В ходе исследования построены гистограммы CpG-островков SARS-CoV, MERS-CoV и SARS-CoV-2 и совмещены соответственно с РНК вирусов для визуализации попадания пиков гистограмм на промоторные участки генов.

Заключение и доступность: 1. В геноме SARS-CoV-2 выявлены сайты зрелой РНК и премикроРНК. 2. Высокая плотность CpG-островков обнаружена в промоторных участках генов. 3. Наибольшее количество $\mathrm{CpG}$-островков приходится на геном MERS-CoV, а наименьшее - на SARS-CoV-2, что свидетельствует о его повышенной способности к репликации и инфекционности.

Список литературы

1. Pruimboom L. Methylation Pathways and SARS-CoV-2 Lung Infiltration and Cell Membrane-Virus Fusion Are Both Subject to Epigenetics. Front. Cell. Infect. Microbiol. 2020;10:290. 